\title{
“Love to Justice, and a Wish to Promote It:" The Politics of Slavery in New Jersey 1770-1775 By Bruce A. Bendler
}

\section{DOI: http://dx.doi.org/10.14713/njs.v3i1.64}

In November 1773, a bill to forbid the importation of slaves into New Jersey, and ease the colony's rigid requirements for manumission, was introduced in the colonial Assembly. This effort was led by Quakers who opposed slavery, but realized that full and immediate abolition was not politically possible. They thus chose the more politically realistic objectives of placing restrictions on slave importation and easing requirements for manumission. Because of growing opposition to even those measures, the bill failed to win passage. This paper argues that efforts to enact this bill formed part of a well-coordinated effort to restrict slavery in late colonial New Jersey, led by Samuel Allinson of Burlington and his allies in the colonial Assembly. Allinson also secured the support of noted abolitionists Anthony Benezet of Philadelphia and Granville Sharp of England. Furthermore, he employed rhetoric in his efforts to restrict slavery similar to that employed in concurrent protests against British encroachments on colonial liberties. Although the bill did not pass, Allinson's correspondence with Benezet and Sharp, the numerous petitions presented in its support, and the publications urging its enactment, prove that there was a serious and wellorganized movement in New Jersey to restrict slavery just before the Revolution, with the ultimate goal of its abolition.

On March 19, 1767, the Virginia Gazette published an article by Arthur Lee calling slavery "a violation of justice and religion." Lee also set forth that freedom was "unquestionably the birthright of all mankind."1 Lee's statements echoed those of Quakers in the mid-Atlantic who had in 1758 banned the purchase or importation of slaves by their members and sought to end slave

\footnotetext{
${ }^{1}$ Virginia Gazette (Williamsburg, Virginia), March 19, 1767.
} 
ownership entirely within their fellowship. Quaker leaders such as Anthony Benezet and David Cooper had moved to the forefront of anti-slavery activity in the Philadelphia Yearly Meeting of the Society of Friends. Within a few years, Quakers in New Jersey moved their efforts into the public arena and sought to persuade their legislature to ban the importation of slaves into the colony, and to ease the colony's rigid requirements for the manumission of slaves. Quakers set forth both of these proposals with the ultimate goal of the total abolition of slavery in mind, but they adopted a pragmatic approach attuned to contemporary political sentiment to attain that goal. ${ }^{2}$

Attainment of that goal motivated Quakers to assert their influence in the public sphere throughout the Revolutionary era. Historian Larry Gerlach argued that New Jersey Quakers, late in 1773, launched a "loosely organized drive" to abolish slavery in the colony. Historian William C. diGiacomantonio pointed out that, some years later, mid-Atlantic Quakers led a more sophisticated effort to convince the first Congress of the United States elected under the Constitution of 1787 to regulate and restrict the slave trade. Quakers presented petitions to one of the first sessions of that Congress in 1790 to promote that objective. The effort launched in 1773 was much more organized and coordinated than would at first appear by reading contemporary legislative records; it foreshadowed later efforts at the state and national level, such as that of 1790. Indeed, it formed part of a much larger effort initiated in the early 1770s and coordinated in large measure by Anthony Benezet to realize the goal of banning the importation of slaves in the midAtlantic and Chesapeake. ${ }^{3}$

\footnotetext{
${ }^{2}$ Much has been written about the development of an anti-slavery consensus within the Quaker community. See Gary B. Nash and Jean R. Soderlund, Freedom by Degree: Emancipation in Pennsylvania and its Aftermath (New York: Oxford University Press, 1991); Jack D. Marietta, The Reformation of American Quakerism, 1748-1783 (Philadelphia: University of Pennsylvania Press, 1984); and Maurice Jackson, Let this Voice Be Heard: Anthony Benezet, Father of Atlantic Abolitionism (Philadelphia: University of Pennsylvania Press, 2012). For a study of abolitionist efforts in the political arena, see Arthur Zilversmit, The First Emancipation: The Abolition of Slavery in the North (Chicago: University of Chicago Press, 1967).

${ }^{3}$ Larry R. Gerlach, Prologue to Independence: New Jersey and the Coming of the American Revolution (New Brunswick: Rutgers University Press, 1976), 240; and William C. diGiacomantonio, "For the Gratification of a
} 
Trans-Atlantic abolitionist networks had begun to form in the decade before the American Revolution. A network of anti-slavery polemicists formed "in the context of the collapse of the first British empire." But such "networking” had begun even before the Anglo-American conflict intensified. The wealthy Virginia merchant Robert Pleasants, himself a Quaker, began to correspond with Anthony Benezet by 1765 . Benezet himself initiated correspondence with leading Quakers in other colonies, including those in New Jersey. Benezet had done much to initiate transAtlantic networks; he also did much to initiate local networks. He recognized the need for action across the British Empire, but he concurrently recognized the need for local and intra-colonial action. $^{4}$

Benezet thus forged ties with British abolitionists such as Granville Sharp, and sought the support of Benjamin Franklin, then in London. ${ }^{5}$ He also forged such connections at the local level. In New Jersey, he corresponded with and befriended Samuel Allinson, who had political connections both in his home town of Burlington and elsewhere in that colony. Allinson wanted the colony's Assembly to ban the importation of slaves, as well as to ease the colony's strict requirements for manumitting slaves. He reached out to his fellow Quakers, but he also sought to persuade influential non-Quakers in the Assembly to support such action. Although unsuccessful in the short term, Allinson's efforts made manifest a high level of planning, adaptation, and organization.

Volunteering Society: Antislavery and Pressure Group Politics at the First Federal Congress" in Journal of the Early Republic 15 no. 2 (Summer 1995), 169-187.

${ }^{4}$ Francois Furstenberg, "Atlantic Slavery, Atlantic Freedom: George Washington, Slavery, and Transatlantic Abolitionist Networks" in William and Mary Quarterly 68 no. 2 (April 2011), 247-286, and Jonathan D. Sassi, "With a Little Help from their Friends: The Quaker and Tactical Contexts of Anthony Benezet's Abolitionist Publishing" in Pennsylvania Magazine of History and Biography 135 no.1 (January 2011), 33-71.

${ }^{5}$ See William B. Willcox, ed., The Papers of Benjamin Franklin 20 (New Haven: Yale University Press, 1976), 4041. 
By the early 1770s, many Americans who, like Allinson, opposed slavery realized that the complete abolition of slavery was not a politically realistic goal. Quakers themselves had moved toward their anti-slavery position only over several generations, and the Philadelphia Yearly Meeting did not mandate that all slaves owned by its membership be set free until 1776. Nonetheless, a diligent effort emerged to place restrictions on the "peculiar institution." Two more limited goals thus emerged - restricting the importation of slaves into the colonies and easing legal requirements for their manumission. Anthony Benezet clearly believed that the abolition of the slave trade was a vital first step toward full emancipation. Additionally, sentiment for such a ban had developed in other colonies where little widespread sentiment existed for full abolition, such as Maryland and Virginia. Benezet focused his efforts on the mid-Atlantic, where abolitionist sentiment was greater, and economic dependence on slavery was less, than in the Chesapeake colonies. $^{6}$

Furthermore, the James Somerset case in Great Britain provided encouragement to abolitionists in British North America. In 1772, the Lord Chief Justice, the $1^{\text {st }}$ Earl of Mansfield, had ruled that James Somerset, a Caribbean slave brought into Britain by his owner, was free upon setting foot on the soil of the British Isles. The Somerset case did not bring about full emancipation throughout the Empire, and its impact in the British Isles themselves was debated. But some

\footnotetext{
${ }^{6}$ Zilversmit 85-9. Christopher Leslie Brown acknowledged Benezet's effort to "look beyond the borders of the Society of Friends" and consider the matter in imperial and Atlantic contexts. Benezet also sought to bring "regional leaders" into that larger context, thus linking local and imperial efforts against slavery. See Brown, Moral Capital: The Foundations of British Abolitionism (Chapel Hill: The University of North Carolina Press, 2006), 396-7. Gregory Dowd Evens pointed out three factors that hindered abolition in Revolutionary New Jersey: respect for property rights, racism, and fear of a large population of free blacks, sometimes "expressed in republican terms." Dowd, "Declarations of Dependence: War and Inequality in Revolutionary New Jersey" in Maxine N. Lurie, editor, A New Jersey Anthology (Newark: New Jersey Historical Society, 1994), 95-120.
} 
abolitionists so construed that decision to argue that it did require emancipation both in the colonies and the homeland. ${ }^{7}$

Many Americans sought action by the British Parliament to end the slave trade, while others looked askance at Parliamentary intervention in the context of the ongoing dispute with Great Britain about Parliamentary authority over the colonies. Granville Sharp, both an abolitionist and an advocate of colonial rights, cautioned Benezet about too much reliance on Parliamentary action. On August 21, 1772, Sharp cautioned Benezet that "with respect to the toleration of slavery in the colonies," Parliament "has no right to interfere." Instead, Sharp urged Americans to petition the King in Council to give the required royal assent to acts of colonial legislatures who themselves took the initiative to ban the importation of slaves. ${ }^{8}$

Benezet's most significant contact in New Jersey was Samuel Allinson, a politically wellconnected Quaker attorney in Burlington. Allinson had risen through the ranks of the provincial government, winning appointment as Surrogate of the Prerogative Court in 1761, Keeper of the Seal in 1762, and Clerk and Register of the High Court of Chancery in 1765. He had also won appointment as Solicitor and Councillor in 1765. While gaining such offices with their attendant political influence, he retained his Quaker identity and principles.

As he rose through the ranks of New Jersey's late colonial political establishment, Allinson also assumed positions of leadership in the colony's Quaker community. By 1764, Allinson served as a representative from the Burlington Monthly Meeting to the Quarterly Meeting which

\footnotetext{
${ }^{7}$ William M. Wiecek argues for the more limited application of the decision. See Wiecek, "Somerset: Lord Mansfield and the Legitimacy of Slavery in the Anglo-American World" in University of Chicago Law Review 42 no. 1 (Autumn 1974), 86-146. Simon Schama points out that Lord Mansfield's decision held only that an ex-slave in England could not be returned to bondage in a colony, a practice "not found" in the common law. See Schama, Rough Crossings (London: BBC Books, 2005), 61. David Waldstreicher argued that the decision had implications for the AngloAmerican conflict, serving to limit the power of colonial assemblies to protect the prerogatives of slaveholders. See Waldstreicher, "The Wheatleyan Moment" in Early American Studies 9 no.3 (2011), 522-51.

${ }^{8}$ Granville Sharp to Anthony Benezet, August 21, 1772, Folder 10, Allinson Family Papers, Haverford College, Haverford, Pennsylvania (hereafter: Allinson Family Papers).
} 
convened in the same town. He held that position frequently from that year into the 1770 s. In 1771, the Burlington Quarterly Meeting chose him to represent it at the Yearly Meeting for Pennsylvania and New Jersey, another duty he performed with some frequency. Allinson also served on various committees named to deal with the financial and administrative oversight of both the monthly and quarterly meetings. ${ }^{9}$

A network of connections, stretching from Granville Sharp in London to Samuel Allinson in Burlington, but centered on Anthony Benezet in Philadelphia, had emerged by 1772. This network formed an important background for the development of efforts to restrict slavery in New Jersey. Benezet and Sharp corresponded from time to time. Benezet and Allinson would, in time, develop not only a working relationship but a close friendship as well. ${ }^{10}$ Allinson was, in turn, in a position to influence members of the New Jersey Assembly, which convened alternately in Allinson's home of Burlington and in Perth Amboy.

On October 30, 1772, Benezet wrote Allinson about a tract by Sharp, written and published in the wake of the Somerset decision. Benezet also mentioned an "interesting letter from Benjamin Franklin on the same subject," and he further mentioned "help from this side of the water" regarding Parliamentary action on the slavery issue. ${ }^{11}$ Benezet evidently still believed that Parliament had jurisdiction over the matter in spite of Sharp's stated beliefs. He accepted "two

\footnotetext{
${ }^{9}$ Minutes of the Burlington Monthly Meeting (1686-1767; 1770-1781) and the Burlington Quarterly Meetings (17701781), microfilm at the Friends Historical Library, Swarthmore College, Swarthmore, Pennsylvania. J. William Frost noted that Benezet had established a "community of support" in America and Britain that gave him "access to political leaders in Pennsylvania and London." His budding friendship with Allinson extended that access to the political arena in New Jersey. See Frost, "Anthony Benezet: The Emergence of a Weighty Friend" in Quaker History 103:2 (Fall 2014), 1-17. Ellen M. Ross discussed Benezet's goal to realize "the kingdom of God on earth, to make God's love present," making "the personal duties of individual Christians" "national duties." Benezet clearly influenced Allinson who then sought to put in realize Benezet's vision in the political arena within the parameters and limitations of what was possible in that arena. See Ross, ibid., 30-41.

${ }^{10}$ This increasingly close friendship is evidenced by the changing salutations in the Benezet-Allinson correspondence. The salutation changes over the time of their correspondence from "Sir" to "Dear Sam" or "Dear Sammy." See Allinson Family Papers.

${ }^{11}$ Benezet to Allinson, October 30, 1772, Allinson Family Papers.
} 
more petitions" from Samuel Allinson, one to the House of Lords for which he had "as much hopes for as any."12

In February of 1773, the Essex Gazette of Salem, Massachusetts, cited Sharp's reasoning in a discussion of such proposals to petition Parliament. Such petitions were "very proper" if the subject was confined to the Atlantic slave trade. But "with respect to the toleration of slavery in the colonies," Parliament had absolutely no right to interfere. The article reiterated Granville Sharp's argument that colonial petitioners should address such concerns to the King in Council. Echoing Sharp, the writer asserted that only colonial assemblies had the right to prohibit slave importation into their respective colonies. Implicit here was that the colonial assemblies had authority to restrict slavery and should be petitioned as well. ${ }^{13}$ Quakers in New Jersey could thus petition their own Assembly to pursue this limited goal while not losing sight of their own larger goal of full emancipation.

Allinson's own approach to the issue had changed by early 1773. Allinson and Quaker abolitionist William Dillwyn both concluded that a gradual, locally-initiated effort that stressed the dissonance between slavery and concurrent protests against British colonial policies would prove the best way to restrict slavery in New Jersey. Americans' "love of liberty" was not consistent with the "invasion" of the liberty of African slaves. Dillwyn further argued that if Americans needed slavery, Britons might well need tax revenue from their North American colonies to pay down their national debt. Dillwyn reasoned that British authorities could as easily justify Parliamentary taxation of the colonies as Americans could justify the employment of slave labor.

\footnotetext{
12 Allinson to Benezet, November 19, 1772, Allinson Family Papers.
}

${ }^{13}$ Essex Gazette (Salem, Massachusetts), February 2-9, 1773. 
Dillwyn also cited an actuarial table known as the Breslau Bill of Mortality to refute the notion that freed slaves would prove a burden to taxpayers and the communities. He argued that the empirical data used by insurers and other commercial concerns allayed this widely-held fear. Dillwyn still recommended a gradual approach to ending slavery. He argued that "conviction precedes conversion," and easing manumission requirements might well open a path to greater restrictions on slavery itself. Changing hearts and minds took time. ${ }^{14}$

Allinson and Dillwyn thus argued that opponents of slavery should convince their legislators to adopt a gradual approach to emancipation, setting forth arguments that would appeal to non-Quakers. In a preface to the American edition of Granville Sharp's An Essay on Slavery, Allinson stated his conviction that slavery was inconsistent with the British constitution and the teachings of Christianity. He then echoed Dillwyn in raising and refuting the argument that freed slaves would prove a burden to taxpayers and the community at large. With those matters in mind, Allinson argued that New Jersey must embark on a "gradual progression" toward the abolition of slavery. Two steps in that progression would be to ban the importation of slaves and to repeal or modify the manumission law of 1714, which Allinson called "almost a prohibition" of, rather than a "process" for, freeing slaves. ${ }^{15}$

Indeed, New Jersey Quakers moved in that very direction, seeking change through their own elected legislature. The manumission law, in force since 1714, almost amounted to a prohibition. That law required a bond of 200 pounds to insure that freed slaves did not burden the public. Even though the colony did impose a duty on imported slaves, imports remained legal. To

\footnotetext{
${ }^{14}$ William Dillwyn, Brief Considerations on Slavery and the Expediency of its Abolition (Burlington, New Jersey: Isaac Collins, 1773). Arthur Zilversmit saw such proposals as a "first step" toward restricting the "supply" of slaves, thus a step toward full abolition. See Zilversmit, "Liberty and Property: New Jersey and the Abolition of Slavery" in New Jersey History 88 (1970), 215-226.

${ }^{15}$ Granville Sharp, An Essay on Slavery (Burlington, New Jersey: Isaac Collins, 1773). The preface to this publication is attributed to Allinson.
} 
opponents of slavery, changing these laws would be a logical, and politically realistic, starting point from which to move forward.

When the second session of the $22^{\text {nd }}$ Assembly of the Province of New Jersey convened on November 10, 1773, it received, during its nearly four-month sitting, petitions from nine counties-Burlington, Monmouth, Cumberland, Essex, Middlesex, Gloucester, Salem, Somerset, and Hunterdon - and Burlington City calling for some type of restrictions on slavery. ${ }^{16}$ Many of them spoke of the "distressed state" of slaves, the "mischiefs arising from the toleration of personal slavery," and "the calamitous condition" of slaves. Nonetheless, rather than calling for full abolition, the petitioners restricted their requests to easing those rigid requirements for manumission and banning further importation of slaves. ${ }^{17}$

By the 1770s, petitioning had long been a part of political culture in New Jersey and indeed all of Britain's colonies, as it had been in England since the emergence of Parliament centuries before. Through the eighteenth century, New Jerseyans presented petitions to their elected representatives in steadily increasing numbers. At times, petitioners organized informally to bring an issue of local concern before the legislature. Formally established organizations, such as the Society of Friends, also employed the process. In New Jersey, the number of acts passed by the colonial Assembly in direct response to petitions increased from about fourteen per legislative session between 1715 and 1720 to about forty-three between 1760 and 1765 . When Quakers

\footnotetext{
${ }^{16}$ The cities of Burlington and Perth Amboy were entitled to elect two members of the colonial Assembly in New Jersey.

${ }^{17}$ Votes and Proceedings of the General Assembly of the Province of New Jersey, November 10, 1773-March 11, 1774 (Burlington, New Jersey: Isaac Collins, 1774), 19, 22-3, 26, 123, 132-3. James Gigantino discusses the debates on slavery in the 1773-4 sitting of the $22^{\text {nd }}$ Assembly, noting the influence of Benezet, William Dillwyn, Allinson, and Granville Sharp, as well as the emergent opposition. See Gigantino, The Ragged Road to Abolition: Slavery and Freedom in New Jersey 1775-1865 (Philadelphia: University of Pennsylvania Press, 2015), 24-6.
} 
presented their petitions to the Assembly that convened in 1773, they employed a process accepted and respected by custom and tradition. ${ }^{18}$

Successful legislative action entailed persuading a religiously diverse body to agree to the proposals set forth largely by Quakers. Only seven of the thirty Assembly members were Quakers. The $22^{\text {nd }}$ Assembly, elected in 1772, also included ten Presbyterians, five Anglicans, four Dutch Reformed congregants, three Baptists, and one member of unknown religious affiliation. ${ }^{19}$ Quakers thus had to reach beyond their own membership and form political alliances with their colleagues from other denominations. They looked first to counties with sizable Quaker populations, some of which elected both a Quaker and a non-Quaker to represent them. Furthermore, Quakers set forth widely-accepted arguments reflecting those employed to protest the actions of the British Parliament after the end of the Seven Years War.

A petition from Quakers in Salem County, where voters had elected a Quaker and a Baptist to the Assembly, did not arrive in Burlington until February 8, 1774, but it set forth the arguments and objectives in greater detail than the others, combining the political rhetoric of the Revolutionary era with the ethical and religious rhetoric Quakers had directed to their own members for a long time. The petition first set forth the tenets of natural law and the precepts of the British constitution. The "laws of God and nature" stipulated that liberty was the "natural and universal right of man" and could be forfeited only voluntarily or as "satisfaction to public justice."

Slavery also transgressed the British constitution. As myriad petitions and polemics protesting Parliamentary taxation had done, the Quakers from Salem County praised that

\footnotetext{
18 Alison G. Olsen, "Eighteenth Century Colonial Legislatures and Their Constituents," in The Journal of American History 79 no. 2 (September 1992), 543-67. For statistics on New Jersey petitions, Olsen cited Thomas J. Purvis, Politics, Patronage, and Paper Money: Legislative Politics in New Jersey, 1703-1776 (New Brunswick: Rutgers University Press, 1986), 176-7, 179.

${ }^{19}$ Gerlach, Prologue to Independence, 363-9. See Table III for statistics on slavery in New Jersey 1772-90.
} 
“excellent Constitution," with "superior advantages which so eminently distinguish it from all others yet known." The presence of slavery was "inimical and destructive" to the constitution. Quakers clearly sought to present a petition that drew on the rhetoric employed at least since the Stamp Act crisis of 1765, thus establishing a political and rhetorical connection with the nonQuaker majority in Burlington. Even so, Quakers did voice their own religious and ethical objections to slavery. Its consequences proved "greatly pernicious to the morals of the people among whom it prevails" and its practice was inconsistent with the "spirit and tenour" of the Christian religion.

But after excoriating the evils of slavery itself, the petitioners limited their requests to those matters of changing the manumission law and ending slave imports. End the "cruelty and injustice" of the slave trade, the petitioners demanded. "Fellow creatures," "yearly forced from the State of Liberty assigned them by Providence," deserved respect for that divinely ordained state. Owners of slaves already in New Jersey should benefit from "such an alteration of Laws" that would enable them to free their slaves "when so disposed." 20 Quakers in Salem County thus formulated a pragmatic approach, petitioning for limited objectives in the context of their deepening conviction that slavery itself had to be ended.

The numerous petitions advocating restrictions on slavery faced developing opposition, based mainly in Monmouth County and the city of Perth Amboy. Petitioners in those jurisdictions voiced concerns about the "number of petitions" for a bill to allow the "more equitable manumission of slaves" in the colony, fearing that it was "likely to pass." These petitioners argued that the law already on the books was "full as easy to those owners who have a mind to set their slaves free." Any revision of the law's requirements could compromise the "safety" of the

\footnotetext{
${ }^{20}$ Petition of "People called Quakers" from Salem County to the General Assembly of New Jersey, February 8, 1774, Friends Historical Library, Swarthmore College, Swarthmore, Pennsylvania.
} 
province. Furthermore, the petitioners argued that "Negroes, both in slavery and freedom," were "a very dangerous people to have general freedom in any province in His Majesty's dominions." Keeping them in subjection proved very difficult and would become more so if more slaves were "generally set free."

The petitions from Monmouth County ironically concluded with an appeal to "preserve the liberty of the white people in this province." In freeing slaves, the legislature would "bring us into bondage which when once done would be very difficult to get rid of." The "barbarous creatures," if freed, would prove "very disagreeable" and would prove "more likely to set easy under slavery in a strange land." The petitioners expressed the very fear that Allinson and Dillwyn had sought to quell, that a growing free African American population would endanger and circumscribe the freedom of New Jersey's white population. ${ }^{21}$

Another petition from Middletown in Monmouth County raised the specter of increased crime in the community. Free African Americans and slaves had developed the habit of "running about at all time of the night stealing and taking and riding people's horses and other mischiefs in a great degree..." They could get away with such misdeeds by "having a correspondence and recourse to the houses of them already freed." The "more easy freeing of slaves" would be "very pernicious to the publick in general." If anything, the petitioners from Middletown thought the manumission process was "already too easy." 22

Most of the petitions in favor of easing the process of manumission had arrived in Burlington early in the 1773-1774 session, many of them in the session's second week. A few more arrived in early December, and petitions from three more counties, including the one from

\footnotetext{
${ }^{21}$ Legislative Records, Box 1-14, Bureau of Archives and History Papers, New Jersey Department of Archives and Records Management, Trenton, New Jersey.

${ }^{22}$ Ibid., Box 1-18. James Gigantino discusses this rationale in The Ragged Road to Abolition, 25-6, pointing out that it certainly became an impediment to abolition or indeed any effort to restrict slavery.
} 
Salem, did not arrive until February 8, 1774. Only after all of this activity did opponents of easing manumission requirements rouse themselves to action (see Table I, at article's end). Had opposition not arisen, the bill might well have passed the Assembly, as similar measures had in Pennsylvania and Delaware.

To promote the bill, Samuel Allinson had secured the support and assistance of a devout Presbyterian whose influence was growing in New Jersey politics. Elias Boudinot of Essex County worked hand in hand with Allinson to secure the bill's passage. In particular, he apprised Allinson of several significant obstacles. First, Boudinot had encountered “unreasonable prejudices," which he did not specify, among people otherwise fond of the "general idea relating to a freedom from slavery." Boudinot also reckoned with the opposition of Assemblyman Stephen Crane of Essex County. Crane had promised to call on Boudinot, presumably to discuss this bill, but had not done so. Boudinot believed that Crane was not so "easily brought to such a measure" and was "rather resolute in his natural disposition.”

Crane did make the promised visit before Boudinot completed his letter to Allinson. The Essex County Assemblyman talked with Boudinot "very fully," stating the fear expressed in the petitions that a growing number of free African Americans in neighborhoods with slaves "would greatly corrupt" the slave population. With that knowledge, Boudinot urged adoption of a compromise to keep chances of the bill's passage alive. He urged Crane to "aid the measure" by having the bill's text printed in the Assembly's published minutes "for the inspection of the public." Boudinot saw further advantage in such an approach. To Allinson, he confided his fear that quick passage of the bill with a "blunder" could "ruin the law altogether and rivet the chains of slavery on the miserable subjects of it faster than ever." 23

\footnotetext{
${ }^{23}$ Elias Boudinot to Samuel Allinson, Allinson Family Papers, January 29, 1774. J. Earl Thompson noted that Boudinot persisted in his anti-slavery efforts for years to come, supporting such efforts as a member of the First
} 
Boudinot then pointed out one further problem to Allinson. "Rivington's paper," the New York Gazette, had printed a "most ingenerous publication” about James Kinsey on January 27, 1774, challenging his credibility. Kinsey, a Quaker Assemblyman who represented Burlington city and supported Allinson, had written a report on the notorious East Jersey treasury robbery of 1768 that insinuated the innocence of Samuel Ford, accused of masterminding the robbery. The article, fraudulently attributed to Ford's wife Grace, sarcastically praised "the goodness of your [Kinsey's] heart, in undertaking the defense of my absconding husband," and challenging the authority of "GOVERNORS, COURTS of JUSTICE, and MAGISTRATES." The writer urged Kinsey not to "damp your pious zeal" but to "go on, great Sir, in the work you have undertaken" and "be exalted beyond the reach of calumny." 24

Kinsey, in fact, was largely responsible for an Assembly committee report that insinuated Ford's innocence. The dispute over responsibility for the robbery had become part of a political battle between Governor William Franklin and the majority of the Assembly. That battle consumed most of the time that the November 1773-March 1774 session of the Assembly spent on anything, and it pitted Quaker assembly members such as Kinsey against Franklin and the colony's treasurer William Skinner. Quaker Assembly members largely supported Kinsey's findings, thus certainly creating a political division that could have an impact on other legislation largely supported by Quakers. Grace Ford herself disavowed the letter, claiming no intention of

Congress of the United States in 1790. Thompson also noted that Anthony Benezet had worked with Presbyterian Benjamin Rush to enact legislation to raise the import duty on imported slaves in Pennsylvania in 1773 as he worked with Allinson in New Jersey. Thompson pointed to the roles of Boudinot and Rush in a more general awakening among Presbyterians on the slavery question. See Thompson, "Slavery and Presbyterianism in the Revolutionary Era" in The Journal of Presbyterian History, 54 no. 1 (Spring 1976), 121-141.

${ }^{24}$ Ibid. Also see Rivington's New York Gazette, January 27, 1774. Signed “G___ F__, , presumably Grace Ford, the wife of Samuel Ford, who had been implicated in the scandal involving the counterfeiting of New Jersey currency and the misuse of the colony's funds. See W. A. Whitehead, The Robbery of the Treasury of East Jersey and Contemporary Events Read before the New Jersey Historical Society, September 12, 1850 (Newark: Office of the Daily Advertiser, 1850). 
"insulting the character of a Gentleman I never knew of, other wise than from his universal good name."25

A letter to the Pennsylvania Gazette on February 2, 1774, offered support to Allinson and his allies. That letter, simply signed "New Jersey" and dated January 29, optimistically noted that the legislature of New Jersey was "favorably disposed to the rights of mankind," at least "in this instance." The plan "for changing slavery into freedom" offered hope that "poor, tawny Africans" would come to enjoy the liberty "which we boast of as the Excellency of our Constitution." "New Jersey's" polemic revealed the hopes of the bill's idealistic supporters, even as other polemics sought to emphasize the more limited objectives set forth in the bill. ${ }^{26}$ "New Jersey's" hopes of course proved premature; legislators stepped back when petitions opposing the bill arrived in Burlington.

On February 16, 1774, the Assembly followed Boudinot's advice and voted to print the bill in its published minutes, rather than taking final action on it. The final vote on this action was twenty-one in favor to eight opposed, with Assembly members from most of the counties with large Quaker populations, and smaller slave populations (see Table III), in West Jersey supporting the motion. Significantly, the two members from Monmouth County, where petitioners on both sides of the issue had made their wishes known, divided on the measure. The one member from Perth Amboy who voted opposed printing the bill for the electorate's consideration (Table II). ${ }^{27}$

\footnotetext{
25 Ibid., February 24, 1774. For a full account of the treasury scandal and its ramifications, see Larry R. Gerlach, "Politics and Prerogatives: The Robbery of the East Jersey Treasury in 1768" in New Jersey History 90 no. 3 (1972), 133-68.

26 Pennsylvania Gazette, Philadelphia, Pennsylvania, February 2, 1774.

27 The Speaker of the Assembly, Cortlandt Skinner, was from Perth Amboy. By custom, he rarely voted. Votes and Proceedings, 1773-4, 155. Graham Hodges pointed out that Quakers in Monmouth County were less proactive in supporting restrictions on slavery than their counterparts in West Jersey. East Jersey Quakers, under the oversight of the New York Yearly Meeting, "lagged behind" those under the oversight of the Philadelphia Yearly Meeting. Hodges also noted that Monmouth Quakers were "determined not to lose money over conscience." Hodges, Root and Branch: African Americans in New York and East Jersey 1613-1863 (Chapel Hill: University of North Carolina Press, 1999), 125.
} 
When the second session of the $22^{\text {nd }}$ Provincial Assembly adjourned on March 11, 1774, the bill to ease requirements for manumission and ban the importation of slaves into New Jersey remained under consideration. Even so, Samuel Allinson was less than optimistic about its prospects for final passage. In a letter to Granville Sharp, he made note of plans to publish the text of the bill. Most of all, Allinson feared that the delay in final passage would not be beneficial. That delay would only allow "enemies to rise up against it, thinking it strikes their interest." Allinson knew that he had to regroup his forces and adapt his arguments for the bill to win passage at a future sitting of the legislature.

Samuel Allinson thus urged a prudent and cautious strategy to keep the bill alive. He urged wider dissemination of the pamphlet by William Dillwyn published the year before "to recommend the above mentioned bill." Allinson hoped that Dillwyn's arguments would counter opponents' fears and carry the day. He urged "friends of the poor Negroes" to "avoid the neglect of their cause." But at the same time, he urged them to also avoid "an intemperate zeal" repugnant to some Assembly members who might prove pliant to more moderate and practical arguments. "Intemperate zeal" only "retard[ed] their relief which is advancing in many places." 28

Elias Boudinot, who had become a sincere opponent of slavery, followed up on his efforts to work with Allinson. Boudinot had asked Allinson about the history and development of Quaker opposition to slavery, even seeking permission to research the records of the Philadelphia Yearly Meeting on the subject. Boudinot was not able to do that, but Samuel Allinson did send Boudinot extracts of relevant portions of the Meeting's records. Motivated by "love to justice and a wish to promote it," Allinson compiled those extracts and sent them to Boudinot on May 31, 1774. In concluding his letter, Allinson expressed the hope that a perusal of the Quaker records would

\footnotetext{
${ }^{28}$ Allinson to Granville Sharp, May 10, 1774, Allinson Family Papers.
} 
motivate Boudinot to emulate "any part of our conduct" worthy of imitation. He further encouraged Boudinot to improve on that conduct; "we shall be glad to see our deficiencies supplied and ourselves excelled in every virtuous effort, that we may have the task of Rectitude made easier by pursuing the footsteps of better way marks." 29

In the midst of increasing turmoil brought about by the controversy with Great Britain, the issue of slavery receded into the background. Nevertheless, it did not disappear. New Jersey's colonial Assembly, although its legitimacy and authority had eroded as the Provincial Congress took a greater role in governing the colony, still met and still transacted the colony's legislative business. In 1775, three sittings of that Assembly took place. Two of them continued the debate on the bill relating to slavery. But the Assembly repeatedly deferred consideration of the bill and never did reach a final decision. The Provincial Congress, preoccupied with the escalating conflict with Great Britain, did not consider the issue of restricting slavery.

The third sitting of the $22^{\text {nd }}$ Provincial Assembly commenced on January 11,1775 . Ten days after the Speaker called it to order, petitions from "different counties" came before the legislature urging reconsideration and passage of the bill. ${ }^{30}$ Days later, on January 28, petitioners from the town of Woodbridge and Middlesex County made their opposition to the bill known (Table I). ${ }^{31}$ But the Assembly again voted to defer consideration of the bill to its "next session" by a vote of thirteen to ten. Assembly members from four of the county's strongly Quaker counties-Burlington, Gloucester, Hunterdon, and Cumberland-supported the delay. Some of those county delegations less inclined to favor the bill-Monmouth, Essex, and Bergen counties,

\footnotetext{
${ }^{29}$ Samuel Allinson to Elias Boudinot, May 31, 1774. Elias Boudinot Papers, Historical Society of Pennsylvania, Philadelphia, Pennsylvania.

${ }^{30}$ Votes and Proceedings of the General Assembly of New Jersey, $3^{\text {rd }}$ Session, $22^{\text {nd }}$ Provincial Assembly (Burlington: Isaac Collins, 1775), 14.

${ }^{31}$ Ibid., 22.
} 
for example — opposed the deferral, possibly hoping to kill any chance of the bill's passage then and there (Table II). ${ }^{32}$

As the Assembly met, at least one statement of support for the bill appeared in the press. On January 12, 1775, “Benevolus," writing in the New York Journal, called upon the Assembly members to approve the bill. He recited arguments set forth over the previous two years, but he placed those arguments in the context of actions of the Continental Congress that had met in Philadelphia the previous fall. He noted that that Congress's call for an end to the importation of slaves offered a "prudent system of conduct as promises fair to answer the warmest desires of the numerous sons of freedom." Based on the rhetoric and actions of the Continental Congress, "Benevolus" noted Congress's implicit assumption that "slavery to an Englishman is worse than death."

Thus, Americans needed to "inquire into our own conduct, lest we put the most powerful weapons into the hands of our enemies." He further noted that one of Congress's most important recommendations, presumably the one regarding the slave trade, "seems to be generally overlooked." "Benevolus" urged the Assembly not to overlook "the cry of half a million wretched beings." He turned to the Scriptures, pointing out that St. Paul equated "man-stealers" with murderers. ${ }^{33}$ Perpetuation of such sinful behavior would prevent "a favorable answer to our prayers." Every slave was an "unanswerable argument against your own claim to freedom."

"Benevolus" then shifted to more pragmatic political arguments. He did not advocate the immediate abolition of slavery, which would expose the slaves to "poverty and distress" without "properly preparing them for supporting themselves." Nevertheless, the New Jersey Assembly

\footnotetext{
32 Ibid., 46.

${ }^{33}$ I Timothy 1:9-10. The word is translated from the original Greek as "men stealers" in the King James Version, and as "slave traders" in the New International Version, a twentieth century translation of the Scriptures.
} 
could commence "the work of reformation" and "provide for their [the slaves'] rising generation" in a way "pleasing to heaven, and your country." The legislators should provide slaves with "the same strict and impartial justice you require and demand for yourselves." 34

More petitions were presented to this session of the Assembly. These petitions, advocating passage of the bill, succinctly stated similar, and previously stated, objectives. Petitions from Burlington, Somerset, and Middlesex counties stated they were "encouraged by the attention given to former petitions" and called for a "revival" of the bill printed with the minutes of the November 1773-March 1774 session. The petitioners stated their concern for both "the honor of the province" and the "relief of individuals." Hinting at the larger political context, they concluded with a reminder to the members of the Assembly of the need to "shew to the World a Conduct consistent with the Principles of Liberty, which we claim as our Birthright." ${ }^{, 35}$

The colonial Assembly of New Jersey again convened on November 15 and adjourned on December 6, 1775. The committee appointed to deal with unfinished business from the previous session noted the bill to restrict slavery had been "referred" from that session. Additionally, this sitting of the Assembly considered the petition of fifty-two inhabitants of Chesterfield Township in Burlington County. That petition went beyond previous entreaties, calling for an "act to free all the slaves now in the colony." The Assembly members read that petition but tabled it, apparently without further consideration. ${ }^{36}$

At this point, advocates of the "referred" bill unsuccessfully sought to bring it to the Assembly floor. On November 23, 1775, the Assembly rejected, by a vote of thirteen to ten, the

\footnotetext{
${ }^{34}$ Journal (New York, New York), January 12, 1775.

${ }^{35}$ Petitions of the inhabitants of Burlington, Cumberland, and Middlesex counties. Bureau of Archives and History papers, Box 1-19; folders 3, 7, 28. NJDARM, Trenton, New Jersey.

${ }^{36}$ Votes of the General Assembly of the Colony of New Jersey, $2^{\text {nd }}$ Sitting, $4^{\text {th }}$ Session (Burlington, New Jersey: Isaac Collins, 1775), 7-8.
} 
motion "should the bill be committed or not." Members of the strongly Quaker counties supported committal with the exception of Benjamin Holme, a Baptist, of Salem County. East Jersey members again lined up against the motion to force a final decision on a bill that had been under consideration by the legislature for two years. Finally, on the same day, the Assembly voted fifteen to ten, to refer the bill to its next session. Members from the Quaker counties voted to support that motion, presumably seeing no hope for its immediate enactment. ${ }^{37}$

The November-December 1775 session of the colonial-era Provincial Assembly was its last. By then the Provincial Congress effectively governed the colony and would do so until the formal attainment of independence and the implementation of a state constitution. The First General Assembly of the State of New Jersey convened on August 27, 1776. As the successor to the colonial Assembly, that body could act on bills deferred by its predecessor. The slavery bill was among those which the colonial assembly had so deferred. The General Assembly did not act on the bill at the time, and it did not enact such a bill for another decade. In 1786, it finally passed bills easing manumission requirements and banning the importation of slaves.

Ultimately, fear of slave insurrections and a lack of support in the counties of East Jersey doomed efforts to restrict slavery in Revolutionary New Jersey before 1786. Opponents of abolition, or even restrictions on slavery, also sought to "break down the connection between the freedom white Americans fought for from Great Britain and the type of freedom abolitionists wanted to give slaves." 38 In the short term, their efforts proved successful even though Samuel Allinson's strategy seemed for a time to be on the verge of success. Allinson himself persisted, not losing sight of his objective: full emancipation. On July 13, 1778, Allinson wrote Governor William Livingston, urging him to consider "the absolute right of all mankind to be free."

\footnotetext{
${ }^{37}$ Ibid., 13-14.

${ }^{38}$ Gigantino, 30, 72-3.
} 
Speaking of emancipation, Allinson envisioned Livingston as the "happy instrument of procuring its advancement." 39

William Livingston proved receptive to Allinson's entreaties, not only about slavery but also about the plight of Quakers in revolutionary New Jersey. The governor and Allinson exchanged correspondence during the summer of 1778 that raised both issues. Livingston noted his efforts to "lay the foundation for their [the slaves'] manumission;" he had sent a message to the Assembly that he "was entirely of your [Allinson's] sentiments." The "house," believing the state "in too critical a situation to enter on the consideration of it at this time," asked that the governor withdraw his message "in a private way." Even so, Livingston vowed to "push the matter until it is effected," stating his personal belief that slavery was inconsistent with "the principles of Christianity and humanity," as well as "odious and disgraceful," among a people "who have almost idolized liberty." 40

Samuel Allinson acknowledged Livingston's efforts, as he acknowledged his own unawareness of the governor's "kind endeavours for promoting justice and liberty to slaves at the last sessions." He remembered Livingston's support of easing the manumission law; he thus expressed confidence that "thou stood favorable to their cause." Allinson put the matter in the context of his understanding that the United States Congress was to recommend such action to the assemblies of Pennsylvania and other states. And Allinson hoped to send a copy of that proposed legislation to Livingston. By 1778, Governor Livingston firmly supported the efforts initiated in 1773; indeed he supported the total abolition of slavery in New Jersey. ${ }^{41}$ The Governor thus proved instrumental in prodding the legislature to move toward restricting slavery. Even so, the

\footnotetext{
${ }^{39}$ Samuel Allinson to William Livingston, July 13, 1778, in Carl Prince and Dennis P. Ryan, eds., The Papers of William Livingston, Volume 2 (Trenton: New Jersey Historical Commission, 1980), 380-90.

40 William Livingston to Samuel Allinson, July 25, 1778, Ibid., 399-404.

${ }^{41}$ Samuel Allinson to William Livingston, August 12, 1778, Ibid., 407-14.
} 
legislature did not ease manumission requirements until 1786, and it did not enact a gradual emancipation act until 1804.

Quakers, in the short term, thus did not succeed in their efforts. Samuel Allinson and William Dillwyn formulated a politically shrewd strategy that took a gradual approach and emphasized that the cost of manumission to the community would not be as great as its opponents feared. Samuel Allinson employed his political connections in Burlington, and he sought to sway the opinions of persons of influence such as Elias Boudinot, Stephen Crane, and William Livingston to gain non-Quaker support for the effort. Non-Quaker Assembly members from the "Quaker counties" generally supported their Quaker peers. In the end, however, the fear of upheaval, as stated in petitions opposing the bill, proved too much to overcome. Furthermore, the Revolutionary War itself further delayed efforts to enact and implement a significant social change. But ultimately, efforts begun in 1773 overcame the obstacles posed by the upheaval of revolution and war to win legislative enactment. Resistance to easing the plight of slaves during the war clashed with the desire of some New Jerseyans to promote justice. Thus, New Jersey's government advanced along the path to abolition only gradually and cautiously. The upheaval and trauma of war certainly impeded progress toward emancipation, but the ideology of the Revolution assured that the path in that direction remained open. ${ }^{42}$

\section{(Scroll for tables.)}

\footnotetext{
42 Seemingly contradictory arguments, set forth by historians James G. Gigantino and Giles R. Wright, that the Revolution impeded the end of slavery, or that it hastened it, can be reconciled and synthesized. Certainly, New Jersey bore the brunt of fighting in a way that other colonies did not. Gigantino pointed out that such upheaval, coupled with fear of large numbers of free African Americans and more general racial prejudice, in the context of a war-ravaged state, led to a cautious approach to any type of social change. Even so, as Wright argued, the ideology of the Revolution itself, coupled with the moral arguments of New Jersey's sizable Quaker population, in time at least partly overcame resistance, sounding out, in Wright's words, the "death knell" of slavery, even if it was a slow death, in New Jersey. See Gigantino, The Ragged Road to Abolition, and Giles R. Wright, "Moving Toward Breaking the Chains: Black New Jerseyans and the American Revolution" in Barbara Mitnick, ed., New Jersey in the American Revolution (Newark: New Jersey Historical Society, 2005), 113-138.
} 


\section{TABLE I}

Receipt of Petitions related to Slavery, 1773-5

Bill to Ease Manumission Requirements and Ban Slave Importation

November 1773-March 1774 Session

Date

County

Position

November 19, 1773

Burlington City and County

Favored Bill

Monmouth

Cumberland

November 20, 1773

Essex

Favored Bill

Middlesex

November 23, 1773

Burlington City

Favored Bill

Gloucester

November 24, 1773

Gloucester

Favored Bill

November 26, 1773

December 6, 1773

Burlington County

Favored Bill

Middlesex

Favored Bill

December 9, 1773

Hunterdon

Favored Bill

February 8, 1774

Burlington County

Salem

Favored Bill

February 14, 1774

Perth Amboy

Monmouth

Opposed Bill

January 1775 Session

January 21, 1775

January 28, 1775

February 1, 1775

February 6, 1775

February 6, 1775 two counties (unnamed)

Woodbridge, Middlesex

Woodbridge, Middlesex

Middlesex

Monmouth
Favored Bill

Opposed Bill

Opposed Bill

Favored Bill

Opposed Bill

November 1775 Session

November 20, 1775

Chesterfield, Burlington

Favored full abolition 
Table II

Position of County Assembly Members on Restrictions on slavery, 1773-5

Generally Favored Restrictions

Burlington City

Burlington County

Gloucester

Hunterdon

Cumberland

Generally Opposed Restrictions

Essex

Bergen

Morris

Cape May

Sussex

Perth Amboy

Somerset

Divided or Unclear

Morris

Salem

Monmouth 
TABLE III

Slave Population in New Jersey, 1772-1790

1772

$\begin{array}{lrc}\text { County } & \text { Whites } & \text { Blacks } \\ & & \\ \text { Sussex } & 8944 & 285 \\ \text { Hunterdon } & 14510 & 1095 \\ \text { Burlington } & 12393 & 731 \\ \text { Gloucester } & 8438 & 316 \\ \text { Salem } & 5662 & 298 \\ \text { Cumberland } & 4949 & 110 \\ \text { Cape May } & 1648 & 111 \\ \text { Morris } & 11168 & 367 \\ \text { Essex } & & \\ \text { Monmouth } & & \\ \text { Middlesex } & & \\ \text { Bergen } & & \\ \text { Somerset } & & \end{array}$

Whites

18996
18661
17270
12830
9891
7990
2416
15532
16454
14969
14398
10109
10329

1790

Slaves

439

1301

227

191

172

120

141

636

1171

1396

1318

2301

1810
Free Non-whites

65

191

598

342

374

138

14

48

160

353

140

192

147

Source: Peter Wacker, Land and People: A Cultural Geography of Pre-industrial New Jersey Origins and Settlement Pattern (New Brunswick: Rutgers University Press, 1975), 415-6.

Bruce A. Bendler earned his Ph. D. in American history at the University of Delaware in 2000. He has contributed to New Jersey History and Delaware History. He contributed a chapter to James Gigantino, ed., New Jersey in the American Revolution: Where the Battle Front Meets the Home Front (New Brunswick, 2015). He frequently contributes to the newsletter of the Salem County Historical Society. He is an adjunct professor of history at the University of Delaware. 